\title{
Hydrometallurgical Treatment of Converter Dust from Secondary Copper Production: A Study of the Lead Cementation from Acetate Solution
}

\author{
Martina Laubertová ${ }^{1, *(\mathbb{D})}$, Alexandra Kollová ${ }^{1}$, Jarmila Trpčevská ${ }^{1}$, Beatrice Plešingerová ${ }^{1}$ (D) \\ and Jaroslav Briančin ${ }^{2}$ \\ 1 Faculty of Materials, Metallurgy and Recycling, Technical University of Košice, 04200 Košice, Slovakia; \\ alexandra.kollova@tuke.sk (A.K.); jarmila.trpcevska@tuke.sk (J.T.); beatrice.plesingerova@tuke.sk (B.P.) \\ 2 Institute of Geotechnics SAS, Slovak Academy of Sciences, Watsonova 45, 04001 Košice, Slovakia; \\ briancin@saske.sk \\ * Correspondence: martina.laubertova@tuke.sk
}

\section{check for} updates

Citation: Laubertová, M.; Kollová, A.; Trpčevská, J.; Plešingerová, B.; Briančin, J. Hydrometallurgical Treatment of Converter Dust from Secondary Copper Production: A Study of the Lead Cementation from Acetate Solution. Minerals 2021, 11, 1326. https://doi.org/10.3390/ $\min 11121326$

Academic Editors: Shuai Wang, Xingjie Wang and Jia Yang

Received: 31 October 2021 Accepted: 23 November 2021 Published: 27 November 2021

Publisher's Note: MDPI stays neutral with regard to jurisdictional claims in published maps and institutional affiliations.

Copyright: (c) 2021 by the authors. Licensee MDPI, Basel, Switzerland. This article is an open access article distributed under the terms and conditions of the Creative Commons Attribution (CC BY) license (https:/ / creativecommons.org/licenses/by/ $4.0 /)$.

\begin{abstract}
The subject of interest in this study was lead cementation with zinc from solution after conventional agitate acidic leaching of converter dust from secondary copper production. The kinetics of lead cementation from an acid solution of lead acetate using zinc powder was studied. The optimal cementation conditions for removing lead from the solution were determined to have a stirring intensity of $300 \mathrm{rpm}$, a zinc particle size distribution $<0.125-0.4>\mathrm{mm}$ and an ambient temperature. Under these conditions, an almost $90 \%$ efficiency in removing lead from solution was achieved. The cementation precipitate contains $\mathrm{Pb}$, and a certain amount of $\mathrm{Cu}$. Lead is present in the cementation precipitate in the $\mathrm{PbO}, \mathrm{Pb}_{5} \mathrm{O}_{8}$ and $\mathrm{Pb}\left(\mathrm{Cu}_{2} \mathrm{O}_{2}\right)$ phases. The solution after cementation was also refined from copper. The solution can be used for further processing in order to obtain a marketable $\mathrm{Zn}$-based product. The resulting cementation precipitate can be further processed and modified to obtain a lead-based product. A kinetic study of the process of lead cementation from solution was also carried out. Based on experimental measurements, the value of apparent activation energy (Ea) which was found to be $\sim 18.66 \mathrm{~kJ} \cdot \mathrm{mol}^{-1}$, indicates that this process is diffusion controlled in the temperature range $293-333 \mathrm{~K}$.
\end{abstract}

Keywords: hydrometallurgy; converter dust; secondary copper; cementation; lead

\section{Introduction}

After iron and aluminium, copper is the third most-used industrial metal [1]. Due to its excellent properties such as ductility, malleability, conductivity of electricity or heat and corrosion resistance, copper is currently irreplaceable in the field of electronics. Moreover, in recent years there has been worldwide growth in sales of electric cars, which entails increased consumption of copper in this branch as well. In 2020 the production of refined copper reached 20.1 million tons [2-4].

Primary copper derived from mining activity is produced mainly (around $84 \%$ of total copper production) via the pyrometallurgical route. Alternatively, via the hydrometallurgical route copper is extracted through leaching (solvent extraction) and electrowinning (SX-EW process).

Two of the largest copper producers in 2020 were: Corporación Nacional del Cobre (Codelco), Chile (1,727,000 t Cu) and Glencore, Switzerland (1,258,000 t Cu) [5]. The sole producer of technical grade copper in Slovakia is Kovohuty in Krompachy [6].

Primary copper production consumes much more energy and generates a lot more emissions than the secondary copper recovery processes. Secondary raw materials used for producing copper contain heavy metals such as zinc, tin and lead, which are released from melts in smelting furnaces and converters in the form of dust. The waste from secondary 
copper production consists of various types of dust: shaft furnace dust, converter dust and anode furnace dust, which are extracted by ventilators and captured in filtering units before they can escape up a chimney. Direct return of these dusts into the copper production process is precluded by their high content of metals such as $\mathrm{Zn}, \mathrm{Pb}, \mathrm{Cd}, \mathrm{Sb}$ and $\mathrm{Sn}$. These metals would cause considerable technical problems if the dusts were used in direct processing. They intrude into the production cycle in any case, mostly through the processing of copper scrap from e-waste (discarded electrical and electronic devices) or copper alloys (brasses and bronzes) [7-9]. In 2019 the amount of dust generated in secondary copper production in Slovakia totalled $2370.27 \mathrm{t}$ [10]. Copper smelting flue dusts are defined as "hazardous materials" according to the current European Waste Catalogue and Hazardous Waste List (10 0603 flue-gas dust \& 100606 solid wastes from gas treatment). This classification of the dusts is mainly due to their high content of compounds with the presence of arsenic and lead [11-13].

The potential for dust recycling lies in its hydrometallurgical processing with the aim of recovering commercial products based on $\mathrm{Zn}, \mathrm{Pb}$ and $\mathrm{Sn}[14,15]$. From the physical point of view, converter dust from secondary copper production consists of a grey-coloured powder particles with principal components of $\mathrm{ZnO}, \mathrm{Pb}_{2} \mathrm{OCl}_{2}, \mathrm{PbO}$ and some other metal oxides. The lead contained in converter dust from secondary copper production needs to be removed before any further processing of the dust [16].

The authors of individual articles cited here have dealt with hydrometallurgical processing of various types of metal-bearing waste containing lead, for instance dusts $[15,17-19]$, lead paste from batteries [20,21], waste from zinc production [22-24] and residual lead in slags $[25,26]$. In some cases, mechanical preparation of material was required prior to hydrometallurgical processing. Authors used in mechanical treatment of sample the Falcon gravity concentrator and Knelson gravity concentrator [17]. Mechanical pretreatment was also used on the slag where was ground to less than $1 \mathrm{~mm}$ and the samples of the copper smelting dust were dried, ground and sieved, which ensured them to have a size of grains less than 200-mesh [27,28]. The samples were air-dried for 30 days, lightly pulverized with agate mortar and pestle, and dry-sieved to obtain sample with particles passing $106 \mu \mathrm{m}$ fraction and also the sample was dried and pulverized to- 100 mesh $(150 \mu \mathrm{m})[24,29]$. The basis for each hydrometallurgical process is leaching. It has been established that the degree of porosity in solid particles influences the rate of diffusion, which in turn affects the efficiency of leaching of prepared material [17]. Hydrometallurgical processing of the types of waste in the above-mentioned studies involved the use either of alkali leaching or acid leaching. The leaching of copper dust was provided in solution of $1-4 \mathrm{M} \mathrm{NaOH}$ at temperature of $20-80{ }^{\circ} \mathrm{C}$ and the solid to liquid ratio 20 . The results obtained were confirmed to exclude $\mathrm{Pb}$ in the solution; with the highest extraction $60 \% \mathrm{~Pb}$ at $2 \mathrm{M} \mathrm{NaOH}$ after $15 \mathrm{~min}$ at $80^{\circ} \mathrm{C}$. $\mathrm{Zn}$ extraction $58 \%$ was achieved at $4 \mathrm{M} \mathrm{NaOH}$ in $15 \mathrm{~min}$ at $80^{\circ} \mathrm{C}$ [19]. Dust was leached with an alkaline solution $\left(\left(\mathrm{NH}_{4}\right)_{2} \mathrm{CO}_{3}\right.$ and $\left.\mathrm{NH}_{4} \mathrm{OH}\right)$ to solubilize $\mathrm{ZnO}$ and $\mathrm{Zn}$ metal where copper, lead, tin and most of the zinc were dissolved in the leach step. Copper, lead and tin were recovered in the cement product [30]. Lead was recovered by cementation from industrial lead sludge solutions of urea acetate using different types of metallic iron [21] and the influence of temperature, sulphuric acid concentration and weight of sample were investigated to recovery zinc and copper from shaft furnace dust [31].

Leaching of lead and zinc from copper shaft furnace dust in $\mathrm{NaOH}$ solution is described by following Equations (1)-(3) [19].

$$
\begin{gathered}
\mathrm{PbO}+\mathrm{NaOH}=\mathrm{Na}^{+}+\mathrm{HPbO}_{2}^{-} \\
\mathrm{PbSO}_{4}+2 \mathrm{Na}^{+}+3 \mathrm{OH}^{-}=\mathrm{HPbO}_{2}^{-}+\mathrm{Na}_{2} \mathrm{SO}_{4}+\mathrm{H}_{2} \mathrm{O} \\
\mathrm{ZnO}+2 \mathrm{NaOH}=\mathrm{ZnO}_{2}^{2-}+2 \mathrm{Na}^{+}+\mathrm{H}_{2} \mathrm{O}
\end{gathered}
$$


Following Equations (4) and (5) occur simultaneously and describes leaching reaction of oxidised copper and lead from slag produced from flash smelting copper concentrates in citric acid solution [27].

$$
\begin{gathered}
\mathrm{CuO}+\mathrm{C}_{6} \mathrm{H}_{8} \mathrm{O}_{7}=\mathrm{Cu}^{2+}+\mathrm{C}_{6} \mathrm{H}_{6} \mathrm{O}_{7}^{2-}+\mathrm{H}_{2} \mathrm{O} \\
\mathrm{PbO}+\mathrm{C}_{6} \mathrm{H}_{8} \mathrm{O}_{7}=\mathrm{Cu}^{2+}+\mathrm{C}_{6} \mathrm{H}_{6} \mathrm{O}_{7}^{2-}+\mathrm{H}_{2} \mathrm{O}
\end{gathered}
$$

Leaching efficiency may be increased through the application of intensification methods during the leaching process, such as using oxidizing agents (hydrogen peroxide $\mathrm{H}_{2} \mathrm{O}_{2}$ [28], ozone $\mathrm{O}_{3}$ [32]) or microwave radiation [33,34]. The highest efficiency achieved in leaching lead out of dusts in a citric acid medium was 84.67\% [27] and in alkali leaching the highest lead extraction (92.84\%) was reached after 30 min using microwave energy for leaching EAF dust in $\mathrm{NaOH}$ solution [34]. Leaching is followed by extraction processes involving various methods including electrolysis, cementation, removal of compounds with low solubility (precipitation with chemical agents), salts crystallization, ion exchange, liquids extraction or adsorption [7]. One of the extraction methods with very high efficiency of recovering lead from solution is cementation. Cementation is the process of extracting the metals from solution based on the electrochemical reaction between the cementing metal (zinc, iron) and the ion of the precipitated metal (lead). The electrode potential of the displacing metal must be more negative than that of the displaced one. Cementation is a simple and easy method that has been used for centuries in hydrometallurgy. The method is used for purification of leaching solutions and for recovery of valuable metals as well [20-22,24,25,35-40]. Various factors have been observed influencing the process and efficiency of cementation. In order to achieve high levels of recovery it is necessary to use from two to four times the stoichiometric amount of cementing metal, high temperature (up to $105^{\circ} \mathrm{C}$ ) or ambient temperature, intensive stirring (110 up to $6000 \mathrm{rpm}$ ) or shaking (e.g., $4 \mathrm{~cm}$ amplitude, 120 shakes/min frequency). Process thermodynamics are influenced by $\mathrm{pH}$ value and redox potential. Modification of $\mathrm{pH}$ before cementation can be performed for instance by adding $\mathrm{NaOH}[41]$ or $\mathrm{H}_{2} \mathrm{SO}_{4}[37,39,42]$. The metals used for cementing in hydrometallurgical processing of waste materials are typically aluminium $[22-25,29,41]$, zinc $[37,39,40,43]$ and iron $[35,36]$, but in one study the researchers used a copper alloy, namely brass [42]. Cementing with iron presents several advantages: removal of heavy metals, simplicity and high speed of the process, the recovery of metals in the form of pure metal.

The general equation of lead cementation with aluminium is described by the Equation (6) [22].

$$
3 \mathrm{~Pb}^{2+}+2 \mathrm{Al}=2 \mathrm{Al}^{3+}+3 \mathrm{~Pb}
$$

The cementation of lead with aluminium from a chloride medium is described by the Equation (7) [25].

$$
3 \mathrm{PbCl}_{2}+2 \mathrm{Al}=2 \mathrm{AlCl}_{3}+3 \mathrm{~Pb}
$$

The cementation of cadmium and lead by zinc in a sulphate medium is described by Equations (8) and (9) [40].

$$
\begin{gathered}
\mathrm{CdSO}_{4}+\mathrm{Zn}=\mathrm{ZnSO}_{4}+\mathrm{Cd} \\
\mathrm{PbSO}_{4}+\mathrm{Zn}=\mathrm{ZnSO}_{4}+\mathrm{Pb}
\end{gathered}
$$

The cementation of copper in the form of $\mathrm{CuSO}_{4}$ by iron is described by the Equation (10) [36].

$$
\mathrm{CuSO}_{4}+\mathrm{Fe}=\mathrm{FeSO}_{4}+\mathrm{Cu}
$$

The most negative standard potential of those three metals has aluminium, but its impact on process kinetics has been observed [22]. Many studies have focused on the application of various metals in copper cementation, and the consensus seems to be that zinc is a more efficient cementer than aluminium or iron. Although aluminium has lower redox potential than zinc, the protective oxidation layer which forms on the surface of 
aluminium during cementation slows the process down, thus reducing the amount of target metal recovered $[37,39,44]$. On the other hand, this passivation layer may be removed by controlling the acidity of the surrounding solution [41]. The selection of cementer metal also depends on the processed material, and if the waste does not contain the given metal, then cementation would lead to contamination and reduced quality of the prepared material. For example, aluminium, zinc or iron can be used for cementation of silver or lead from salt solution, but it has been established that the cementation process runs more slowly with zinc and iron, whereas with aluminium it proceeds faster. Thus, aluminium has been found to be an efficient as well as accessible cementer, and, moreover, less of it is consumed in the process compared with the other two metals [25,29]. The influence of amount and surface morphology of the cementer metal has been observed with regard to the process and result of lead extraction, and the optimal form was found to be powder with micropores [21]. Cementation efficiency is also affected by the presence of specific ions in the solution. For example, cementation of copper using iron proceeded faster in sulphate electrolyte, whereas in iodate solutions the process did not function at all [35]. Regarding results of cementation, almost $100 \%$ extraction has been achieved with lead $[20,22,29,39,40]$, copper $[36,37,39,42]$ and iron [37]. Studies of process kinetics have found that in the cementation of copper using zinc [37], lead using aluminium [22] and lead using iron [38], diffusion-controlled phases occurred within certain temperature intervals (22 to $50{ }^{\circ} \mathrm{C}$ [37], 50 to $70{ }^{\circ} \mathrm{C}$ [22] and 25 to $80{ }^{\circ} \mathrm{C}$ [38]). Cementation of lead using aluminium is highly sensitive to temperature change between $40-50{ }^{\circ} \mathrm{C}$, and in this case the process is controlled by the speed of chemical reaction itself [22]. Generally speaking, lead is cemented not only in the form $\mathrm{Pb}^{0}$, but also $\mathrm{PbO}[23,24]$. In lead cementation moreover, several metals may pass into the precipitate together; for example, in cementing lead using aluminium the precipitate was found to contain aluminium, iron and zinc as well [22]. After processing waste material from zinc production using two-stage leaching in $\mathrm{NaOH}$ followed by cementation using powdered zinc, the resulting product contained more than $99 \% \mathrm{~Pb}$, but silver was also found concentrated within it [23]. The kinetics of cementation processes is generally described as a reaction of the first order, and the step determining the speed of the process is the diffusion-controlled cathode reaction [38,43]. Cementation of copper using zinc is a first-order reaction, and it proceeds with subsequent surface reaction and diffusion-controlled phases [44]. Cementation of copper using aluminium is a first-order reaction as well, and the step determining its speed is the diffusion phase [41].

The insights presented in this theoretical section were applied in the following experimental investigations. The leaching medium used for leaching converter dusts was an acetic acid solution, it was found more effective for metal recovery from the dust. The extraction method selected for extracting lead was cementation, and zinc in metal powder form was used as the cementer. Zinc was chosen as the optimal cementer, since it is contained in the solution after the acid leaching of dusts. The following parameters were monitored for their impact on the speed of the lead cementation process: temperature of the medium, stirring rate and cementer particle size. The aim was to establish the optimal conditions for lead cementation in order to achieve the highest efficiency. The lead was cemented out in the precipitate, and a purified solution was acquired containing zinc for further processing.

\section{Materials and Methods}

In these experiments we used a representative sample of converter dust from secondary copper production. The chemical composition of the dust (see Table 1) was determined using the atomic absorption spectrometry (AAS) method and a Varian Spectrophotometer AA20+ device (Varian, Belrose, Australia). The contents of zinc $29.9 \mathrm{wt} . \%$ and lead $9.33 \mathrm{wt} . \%$ made them the principal representatives among the metals in the dust. 
Table 1. Chemical analysis of converter dust.

\begin{tabular}{ccccccc}
\hline Element & $\mathbf{P b}$ & $\mathbf{Z n}$ & $\mathbf{F e}$ & $\mathbf{C u}$ & $\mathbf{C a}$ & Si \\
\hline Content (wt.\%) & 9.33 & 29.90 & 0.52 & 7.05 & 0.23 & $<$ LoD $^{1}$ \\
\hline
\end{tabular}

${ }^{1}$ Note: LoD, limit of detection.

Figure 1 presents the distribution of particle sizes in the converter dust. The graphic shows that the particle distribution was bimodal. The predominant portion of the dust occupied the particle size range below $10 \mu \mathrm{m}$. Small particle size is in fact advantageous in hydrometallurgical processing. The average unit weight of converter dust is $3.4165 \mathrm{~g} \cdot \mathrm{cm}^{-3}$ with a standard deviation of $0.0071 \mathrm{~g} \cdot \mathrm{cm}^{-3}[8]$.

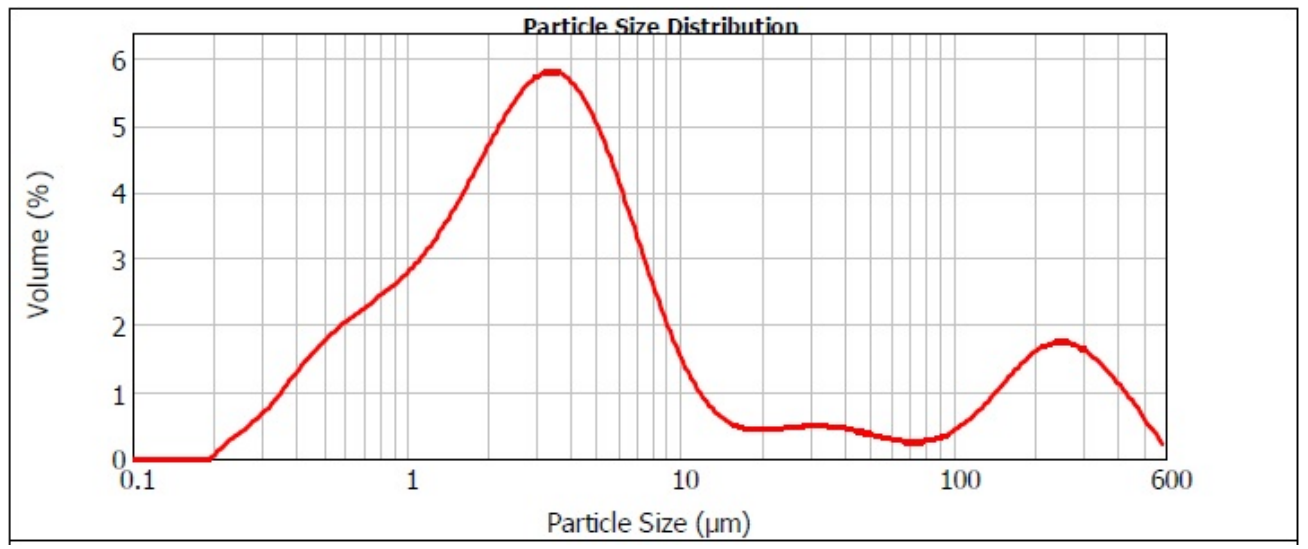

Figure 1. Distribution of particle sizes in our converter dust.

The morphology of the particles under $100 \times$ magnifications using a Dino-Lite Pro AM4113T optical stereo microscope (AnMo Electronics Corporation, Hsinch, Taiwan) is presented in Figure 2a. The sample was composed of two fractions: coarse and fine spherical grains, and the larger-size grains were covered in the smaller ones. X-ray diffraction phase analysis (XRD) (PANanalytical, Malvern, UK) produced results shown in Figure 2b, and it was found that zinc was present in the dust in the form of zincite ( $\mathrm{ZnO})$. Lead was found in the dust in the mainly form of oxides. Results of leachability testing indicated that this converter dust should be stored only in a hazardous waste dump [8]. Figure 2c, d document the results of SEM and EDX analyses of particles in the dust sample. The EDX analysis shows that the elements predominately represented were $\mathrm{Zn}, \mathrm{O}, \mathrm{Pb}, \mathrm{Cu}$ and $\mathrm{Cl}$.

Our thermodynamic calculations applying Van't Hoff's reaction isobar indicated that chemical reactions (11) and (12) had the highest probability of successful course. Figure $3 a, b$ shows the potential-pH diagrams (Pourbaix diagrams) for the systems $\mathrm{Pb}-\mathrm{C}-\mathrm{H}_{2} \mathrm{O}$ and $\mathrm{Zn}-\mathrm{C}$ $\mathrm{H}_{2} \mathrm{O}$ at $298 \mathrm{~K}$, and it can be seen that lead appears in ion form $\left(\mathrm{Pb}^{2+}\right)$ in the zone of water stability around $298 \mathrm{~K}$ at pH 0 to 2 and $0.0 \mathrm{~V}$ to $1.3 \mathrm{~V}$, and in a narrower zone at $\mathrm{pH} 0$ to 4.8 and $0.0 \mathrm{~V}$ to $0.2 \mathrm{~V}$. Zinc also appears in ion form $\left(\mathrm{Zn}^{2+}\right)$ in the water stability zone at temperature $298 \mathrm{~K}, \mathrm{pH}$ value 0 to 3.4 and $0 \mathrm{~V}$ to $1.2 \mathrm{~V}$, and in a narrower zone at $\mathrm{pH} 3.4$ to 5.6 and 0 to $0.2 \mathrm{~V}$. $\mathrm{PbO}$ dissolves chemically in acetic acid according to Equation (11).

$$
\begin{array}{cc}
2 \mathrm{CH}_{3} \mathrm{COOH}_{(\mathrm{a})}+\mathrm{PbO}=\mathrm{Pb}\left(\mathrm{CH}_{3} \mathrm{COO}\right)_{2(\mathrm{a})}+\mathrm{H}_{2} \mathrm{O} \quad \Delta \mathrm{G}_{293 \mathrm{~K}}^{0}=-19 \mathrm{~kJ} \cdot \mathrm{mol}^{-1} \\
2 \mathrm{CH}_{3} \mathrm{COOH}_{(\mathrm{a})}+\mathrm{ZnO}=\mathrm{Zn}\left(\mathrm{CH}_{3} \mathrm{COO}\right)_{2(\mathrm{a})}+\mathrm{H}_{2} \mathrm{O} \quad \Delta \mathrm{G}_{293 \mathrm{~K}}^{0}=-17.5 \mathrm{~kJ} \cdot \mathrm{mol}^{-1}
\end{array}
$$




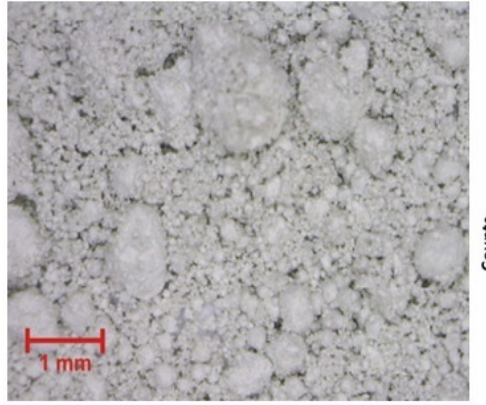

(a)

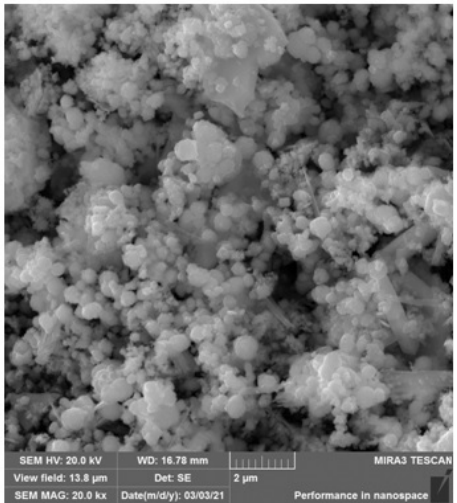

(c)

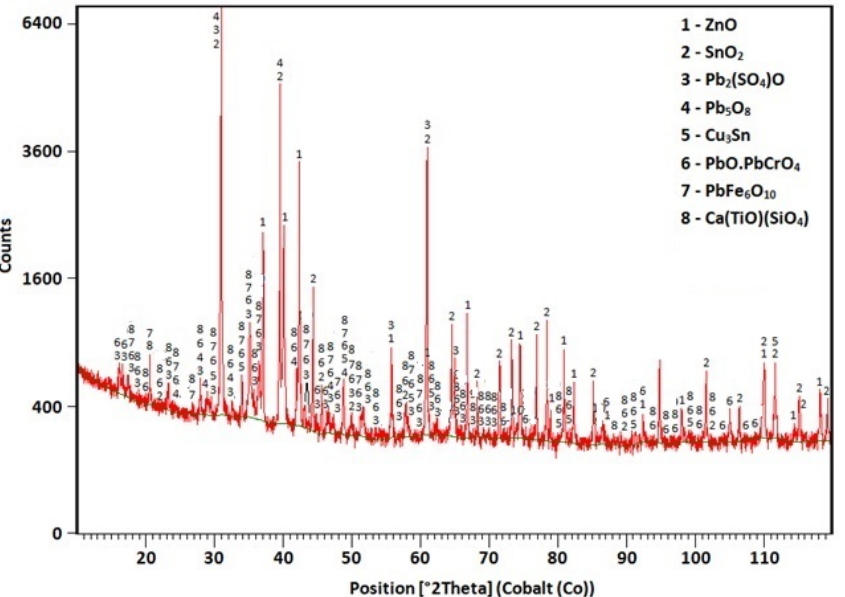

(b)

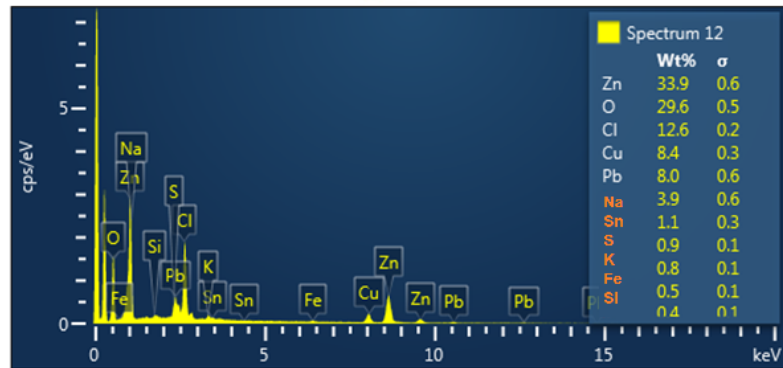

(d)

Figure 2. (a) Morphology of converter dust particles under stereo microscopy; (b) XRD analysis results; (c) SEM analyses, morphology of particles and (d) EDX analyses.

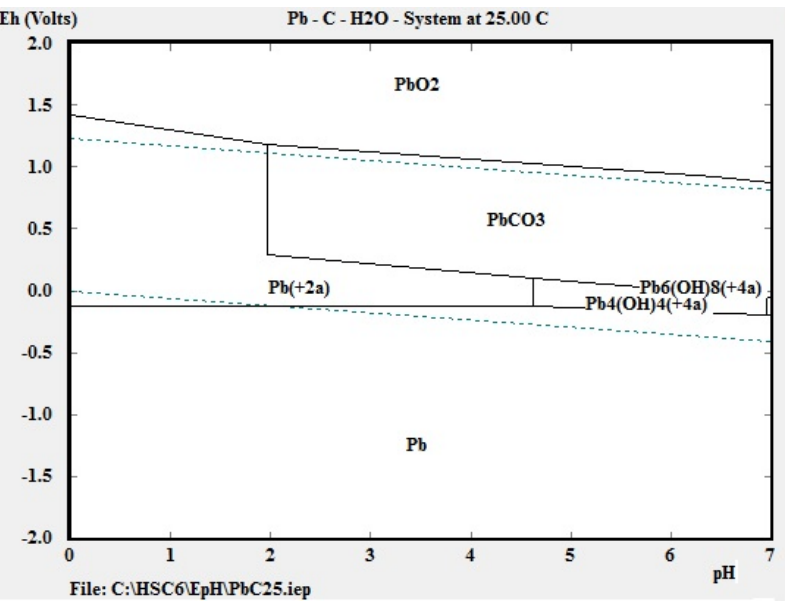

(a)

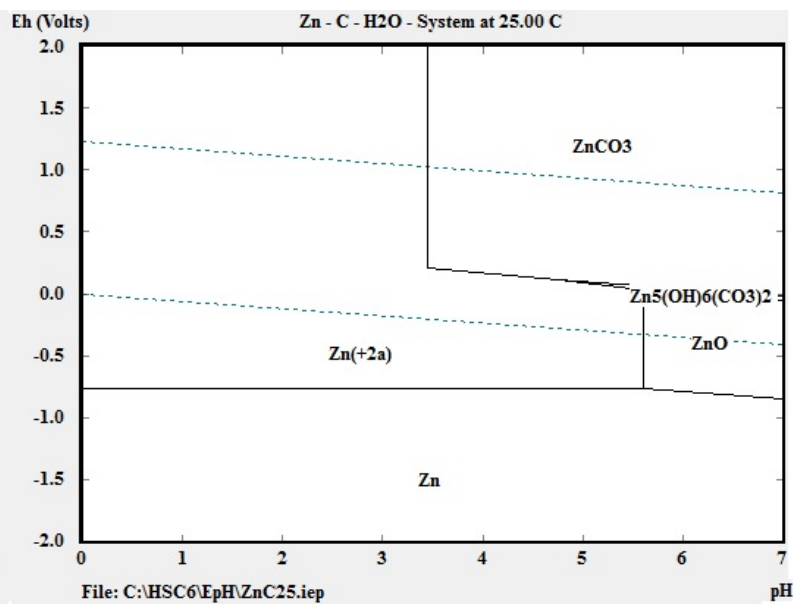

(b)

Figure 3. E-pH diagrams of systems (a) Pb-C- $\mathrm{H}_{2} \mathrm{O}$ and (b) $\mathrm{Zn}-\mathrm{C}-\mathrm{H}_{2} \mathrm{O}$ at $298 \mathrm{~K}$, created with HSC Chemistry software, ver. 6 (Outotec, Espoo, Finland).

For $\mathrm{ZnO}$ the dissolution zones in the E-pH diagram apply between 0 and $5.7 \mathrm{pH}$. The aim of leaching was to transfer lead into the solution under optimal conditions, and from the thermodynamic point of view it may be stated that oxides of $\mathrm{Pb}$ and $\mathrm{Zn}$ will dissolve chemically at temperature $298 \mathrm{~K}$ in an acid medium. It is not necessary to raise the temperature further.

In the first phase of the experiments, we carried out leaching of the converter dust in an acetic acid solution under ambient temperature conditions ( $293 \mathrm{~K})$. The stirring rate was set on the electric stirrer at $400 \mathrm{rpm}$. Acidity of the medium was measured during the 
experiments with a hand-held $\mathrm{pH}$ meter. We started by pouring $500 \mathrm{~mL} 0.4 \mathrm{M}$ solution of acetic acid $\left(\mathrm{C}_{2} \mathrm{H}_{4} \mathrm{O}_{2}\right)$ into a glass vessel, and then added a weighed amount of $12.5 \mathrm{~g}$ of converter dust, producing a liquid/solid phase ratio of 40:1. At the following time intervals: $5,10,15,30$ and $60 \mathrm{~min}$, we drew off $5 \mathrm{~mL}$ samples of the solution for chemical analysis to determine the $\mathrm{Pb}$ and $\mathrm{Zn}$ contents using the atomic absorption spectrometry (AAS) method on a Varian Spectrophotometer AA20+ type device. At the end of the leaching the resulting sediment was recovered by filtering, and subsequently another $10 \mathrm{~mL}$ sample of the solution was taken for final chemical analysis to determine $\mathrm{Pb}, \mathrm{Zn}, \mathrm{Cu}$ and Fe contents by means of AAS method. The solid remnant from filtration was rinsed with $200 \mathrm{~mL}$ distilled water, and then dried and weighed. The remaining solution obtained from the leaching process was later re-used in the second phase of our experiments for studying lead cementation. The results of our analyses are summarized in Table 3 (a). During cementation on zinc of lead and copper obtained from leaching in acid solution, the following Equations take place (13) and (14):

$$
\begin{aligned}
& \mathrm{Zn}_{(\mathrm{s})}+\mathrm{Pb}\left(\mathrm{CH}_{3} \mathrm{CO}_{2}\right)_{2(\mathrm{aq})}=\mathrm{Zn}\left(\mathrm{CH}_{3} \mathrm{COO}\right)_{2(\mathrm{aq})} \mathrm{Pb}_{(\mathrm{s})} \Delta \mathrm{G}_{293 \mathrm{~K}}^{0}=-143.155 \mathrm{~kJ} \cdot \mathrm{mol}^{-1} \\
& \mathrm{Zn}_{(\mathrm{s})} \mathrm{Cu}\left(\mathrm{CH}_{3} \mathrm{CO}_{2}\right)_{2(\mathrm{aq})}=\mathrm{Zn}\left(\mathrm{CH}_{3} \mathrm{COO}\right)_{2(\mathrm{aq})}+\mathrm{Cu}_{(\mathrm{s})} \Delta \mathrm{G}_{293 \mathrm{~K}}^{0}=-211.878 \mathrm{~kJ} \cdot \mathrm{mol}^{-1}
\end{aligned}
$$

The electrode potential of redox vapour $\mathrm{Zn}^{2+} / \mathrm{Zn}^{0}$ is less than that of redox vapours $\mathrm{Pb}^{2+} / \mathrm{Pb}^{0}(15)$ and $\mathrm{Cu}^{2+} / \mathrm{Cu}^{0}(16)$, which is in fact a condition for lead and copper cementation using zinc.

$$
\begin{aligned}
& \mathrm{E}_{\mathrm{Zn}^{2+} / \mathrm{Zn}^{0}}^{0}<\mathrm{E}_{\mathrm{Pb}^{2+} / \mathrm{Pb}^{0}}^{0}-0.763 \mathrm{~V}<-0.126 \mathrm{~V} \\
& \mathrm{E}_{\mathrm{Zn}^{2+} / \mathrm{Zn}^{0}}^{0}<\mathrm{E}_{\mathrm{Cu}^{2+} / \mathrm{Cu}^{0}}^{0} \quad-0.763 \mathrm{~V}<+0.337 \mathrm{~V}
\end{aligned}
$$

The thermodynamic conditions for cementation of lead and copper using powder zinc in the temperature range 293 to $353 \mathrm{~K}$ are described in Equations (13) and (14) presented in Table 2.

Table 2. Thermodynamic conditions for cementing lead and copper using powder zinc.

\begin{tabular}{cc}
\hline $\mathrm{Zn}_{(\mathrm{s})}+\mathrm{Pb}\left(\mathrm{CH}_{3} \mathrm{CO}_{2}\right)_{2(\mathrm{aq})}=\mathrm{Zn}\left(\mathrm{CH}_{3} \mathrm{COO}\right)_{2(\mathrm{aq})}+\mathrm{Pb}_{(\mathrm{s})}$ \\
\hline $\mathbf{T}(\mathbf{K})$ & $\mathbf{\Delta G}(\mathbf{k J})$ \\
\hline 293 & -143.155 \\
313 & -142.094 \\
333 & -141.950 \\
353 & -142.578 \\
\hline $\left.\mathrm{Zn} \mathbf{( s )}_{(\mathrm{Cu}}+\mathrm{CH}_{3} \mathrm{CO}_{2}\right)_{2(\mathrm{aq})}=\mathbf{Z n}\left(\mathrm{CH}_{3} \mathrm{COO}\right)_{2(\mathrm{aq})}+\mathrm{Cu}_{(\mathrm{s})}$ \\
\hline $\mathbf{T}(\mathbf{K})$ & $\mathbf{\Delta G} \mathbf{( k J )}$ \\
\hline 293 & -211.878 \\
313 & -212.397 \\
333 & -212.903 \\
353 & -213.399 \\
\hline
\end{tabular}

In our cementation experiments we focused on investigating the influence of stirring intensity (100, 300 and $400 \mathrm{rpm})$, solution temperature $(293,313,333$ and $353 \mathrm{~K})$ and cementer particle size on the speed of lead cementation. We used powder zinc as cementer with two particle size distribution: $<0.125-0.4>\mathrm{mm}$ and $<0.08-0.125>\mathrm{mm}$. For the purposes of comparing the influence of particulate cementer. We also performed an experiment using a zinc-coated plate with dimensions $(20 \mathrm{~mm} \times 35 \mathrm{~mm} \times 1 \mathrm{~mm})$. The cementation procedure was as follows. First, we poured $100 \mathrm{~mL}$ of solution resulting from leaching into a glass vessel. Then, we added a stoichiometrically-calculated amount of $0.3 \mathrm{~g} \mathrm{Zn}^{0}(\mathrm{~s})$ in powder form, representing the excess of the calculated amount of zinc over 
the amount of lead determined in the solution after leaching. We drew off $5 \mathrm{~mL}$ samples for measuring $\mathrm{Pb}$ and $\mathrm{Cu}$ contents after 5, 10, 15, 30 and 60 min of cementation, or after 0 , $5,10,1530 \mathrm{~min}$, if the cementation procedure lasted only $30 \mathrm{~min}$. Once cementation was completed, the precipitate formed in the solution was recovered by filtering, and then dried, and a representative sample was taken for subsequent analysis. The results were processed using standard mathematical and statistical methods with the aid of generally available computer software: Microsoft Office Excel 2007, (Microsoft Corporation, Redmond, WA, USA), and SigmaPlot 10.0 (Systat Software, Erkrath, Germany). The converter dust and the resulting cementation precipitate were analyzed using combinations of these methods: X-ray diffraction phase analysis (XRD) PANanalytical, Malvern, UK), scanning electron microscopy (SEM) (TESCAN, Brno, Czech Republic) and energy-dispersive X-ray analysis (EDX) (Oxford Instruments, Oxford, UK). A MIRA3 FE-SEM scanning electron microscope (TESCAN, USA) was used for investigating particle morphology. EDX provided semiquantitative element analysis. For qualitative phase analysis we used an X-PANalytical $X^{\prime}$ Pert PRO MRD (Co-K $\alpha$ ) diffractometer (PANanalytical, Malvern, UK). Particle morphology was examined under $100 \times$ magnifications with a Dino-Lite ProAM413T optical stereo microscope device (AnMo Electronics Corporation, Hsinch, Taiwan).

\section{Results and Discussion}

\subsection{Influence of Stirring Intensity}

Experiments started by studying the influence of this variable, maintaining the temperature of the cementation solution containing powder zinc at $293 \mathrm{~K}$. It has been tried three different stirring rates in separate experiments, namely 100, 300 and 400 revolutions per min (rpm). The solution obtained after converter dust leaching by acetic acid was analyzed using the AAS method. The solution contained $1.570 \mathrm{~g} \cdot \mathrm{dm}^{-3} \mathrm{~Pb}$ and $8.756 \mathrm{~g} \cdot \mathrm{dm}^{-3}$ $\mathrm{Zn}$. The dependence on time of lead concentration in the solution is shown in Figure $4 \mathrm{a}$, while Figure $4 \mathrm{~b}$ presents a graphical comparison of lead concentrations after $30 \mathrm{~min}$ of cementation using powder zinc when the three different stirring rates were applied.

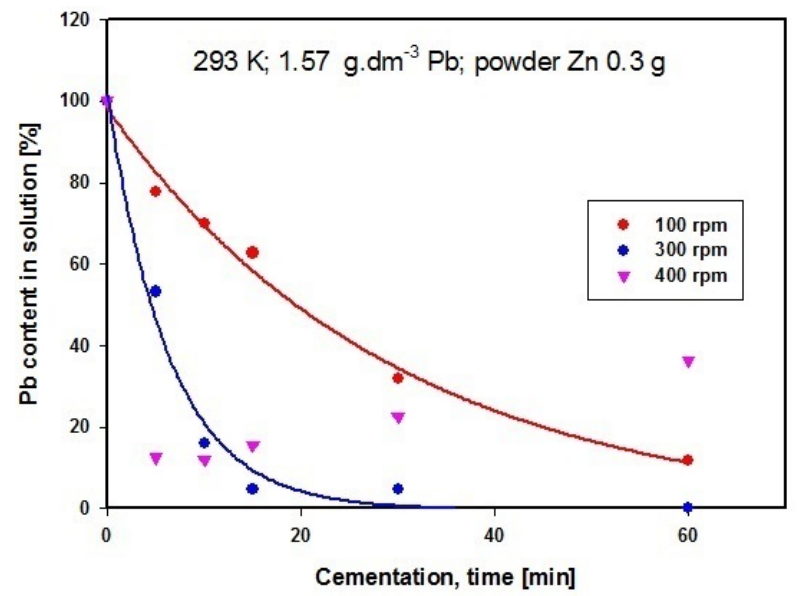

(a)

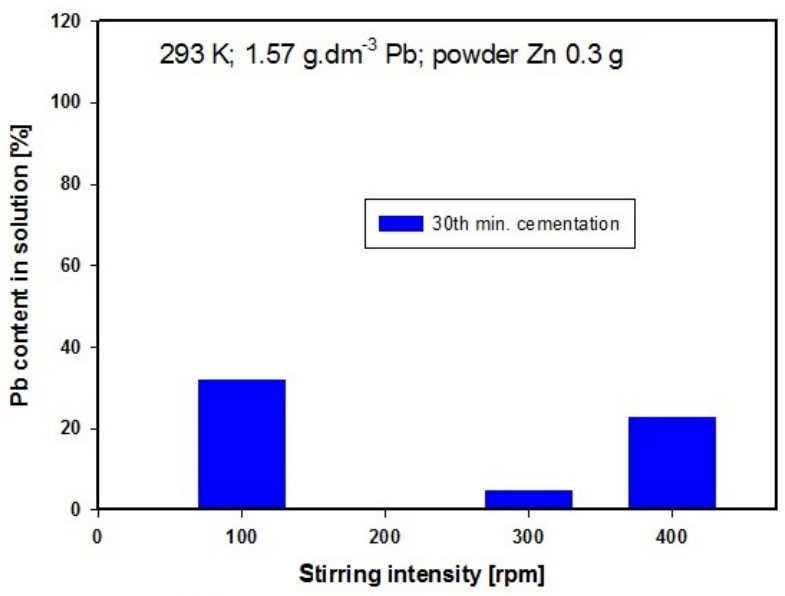

(b)

Figure 4. (a) Time dependence of $\mathrm{Pb}$ concentration in solution after cementation using zinc at different stirring rates at constant temperature; (b) Comparison of $\mathrm{Pb}$ concentrations in solution after cementation using zinc at different stirring rates at constant temperature.

The graph in Figure 4a suggests that the optimal stirring rate for obtaining the lowest lead concentration in the solution is $300 \mathrm{rpm}$, given a cementation period of $30 \mathrm{~min}$, and this is confirmed by the results of comparison of the three different stirring rates presented in Figure $4 \mathrm{~b}$. The zinc content in the solution after cementation using powder zinc remained unchanged. At the higher stirring rate of $400 \mathrm{rpm}$, retroactive leaching of lead was observed, while lower revolutions produced lower lead concentration in the final medium. Optimal 
stirring speed ensured removal of layers of metal deposits $(\mathrm{Pb}$ and $\mathrm{Cu})$ from the surface of the cementer $(\mathrm{Zn})$, thus enabling constant contact between the solution $\left(\mathrm{Pb}\left(\mathrm{CH}_{3} \mathrm{CO}_{2}\right)_{2(\mathrm{aq})}\right.$; $\left.\mathrm{Cu}\left(\mathrm{CH}_{3} \mathrm{COO}\right)_{2(\mathrm{aq})}\right)$ and cementer $\left(\mathrm{Zn}_{(\mathrm{s})}\right)$. Our further experiments were therefore carried out using the optimal stirring intensity of $300 \mathrm{rpm}$.

\subsection{Influence of Temperature}

The influence of temperature was investigated at a constant stirring rate of $300 \mathrm{rpm}$ stirring rate. The initial solution volume was $100 \mathrm{~mL}$, to which we added $0.3 \mathrm{~g}$ of powder zinc. Total duration of each experiment was maintained at $30 \mathrm{~min}$. After the end of cementation, a $10 \mathrm{~mL}$ sample of solution was drawn off for determination of $\mathrm{Pb}, \mathrm{Zn}$ and $\mathrm{Cu}$ contents. Individual experiments were performed at temperatures of $293 \mathrm{~K}, 313 \mathrm{~K}$, $333 \mathrm{~K}$ and $353 \mathrm{~K}$. Figure $5 \mathrm{a}$ is a graphical representation of the influence of temperature on lead content in the solution expressed in percentages, and Figure $5 \mathrm{~b}$ shows the results of comparing lead concentration after five minutes of cementation at temperatures 293, 313,333 and $353 \mathrm{~K}$. The graph in Figure 5c shows the changes in concentrations of $\mathrm{Pb}, \mathrm{Zn}$ and $\mathrm{Cu}$ in the solution during cementation using zinc at $293 \mathrm{~K}$. A graphical comparison of cementation efficiency for lead and copper at $293 \mathrm{~K}$ is given in Figure $5 \mathrm{~d}$, where the efficiency for $\mathrm{Cu}$ is seen to be $100 \%$, while that for $\mathrm{Pb}$ is 87.13 . The reaction occurring during cementation of $\mathrm{Cu}$ using $\mathrm{Zn}$ (Equation (14)) has more negative value for Gibbs energy than the reaction during cementation of $\mathrm{Pb}$ using $\mathrm{Zn}$ (Equation (13)) within the temperature range applied in these experiments 293-353 K. It follows from this that cementation of $\mathrm{Cu}$ on $\mathrm{Zn}$ is more likely to happen than cementation of $\mathrm{Pb}$ on $\mathrm{Zn}$, and this is the reason why the efficiency of $\mathrm{Cu}$ cementation is higher than that for $\mathrm{Pb}$ (see also Figure $5 \mathrm{~d}$ below).

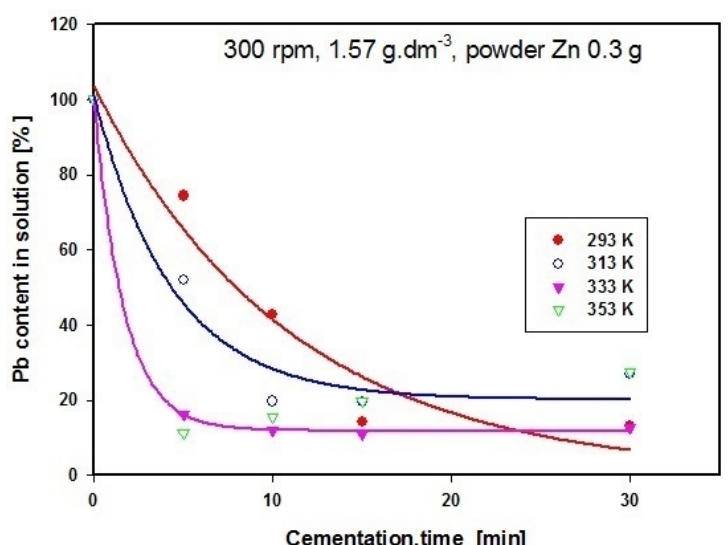

(a)

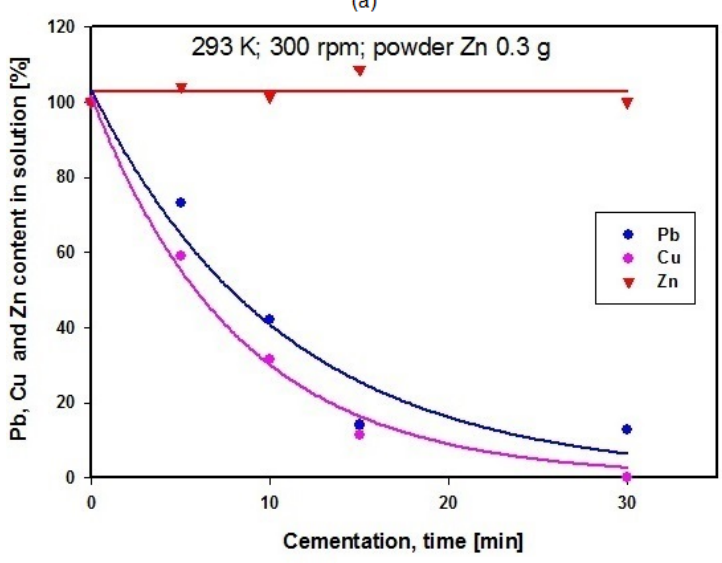

(c)

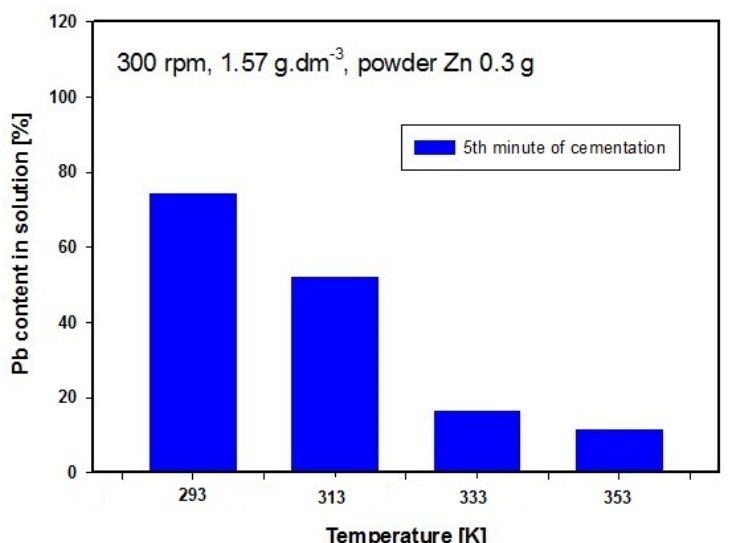

(b)

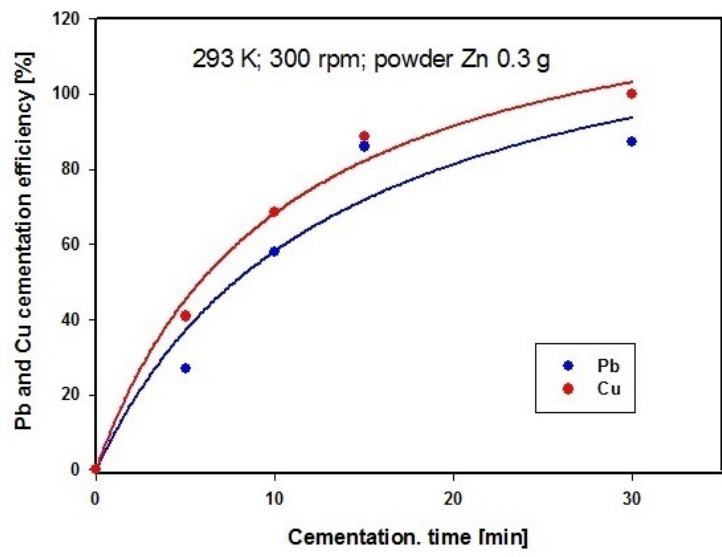

(d)

Figure 5. (a) Time dependence of $\mathrm{Pb}$ content in solution during cementation at different temperatures; (b) Comparison of $\mathrm{Pb}$ concentrations after 5 min cementation at different temperatures; (c) Time dependence of $\mathrm{Pb}, \mathrm{Cu}$ and $\mathrm{Zn}$ concentrations in solution during cementation using zinc; (d) Comparison of $\mathrm{Pb}$ and $\mathrm{Cu}$ cementation efficiencies at $293 \mathrm{~K}$. 
The morphology of cementation precipitate particles under $100 \times$ magnification using a Dino-Lite ProAM413T optical stereomicroscope is presented in Figure 6a. The image clearly shows the variety of shapes and sizes of particles ranging from 1 to $1.5 \mathrm{~mm}$. XRD analysis (see image in Figure $6 \mathrm{~b}$ revealed that lead was contained in the precipitate in phases $\mathrm{PbO}, \mathrm{Pb}_{5} \mathrm{O}_{8}$ and $\mathrm{Pb}\left(\mathrm{Cu}_{2} \mathrm{O}_{2}\right)$, and copper in the forms $\mathrm{Cu}, \mathrm{Cu}(\mathrm{OH})_{2}$ and $\mathrm{Cu}_{4} \mathrm{Zn}$.

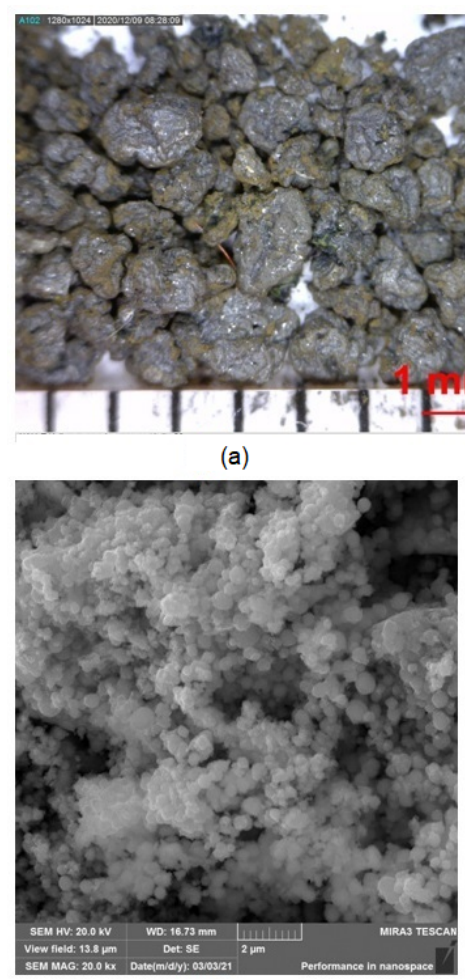

(c)

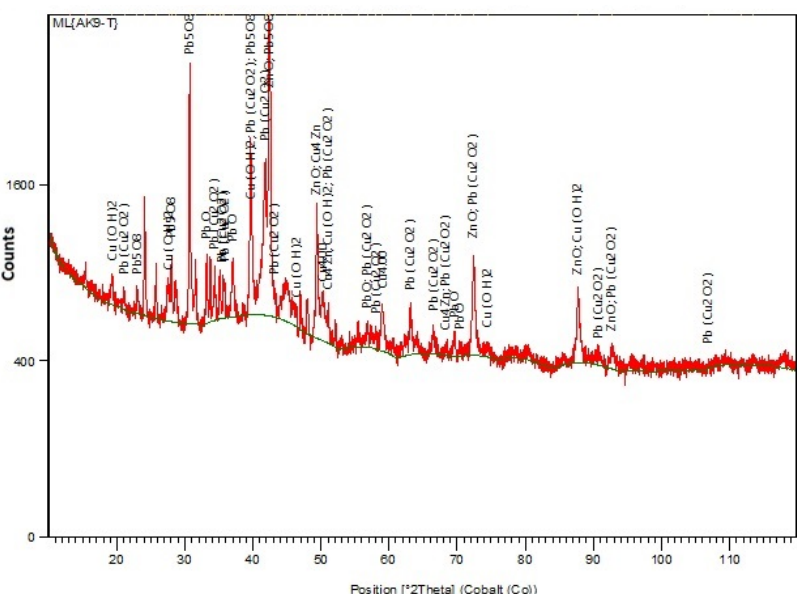

(b)

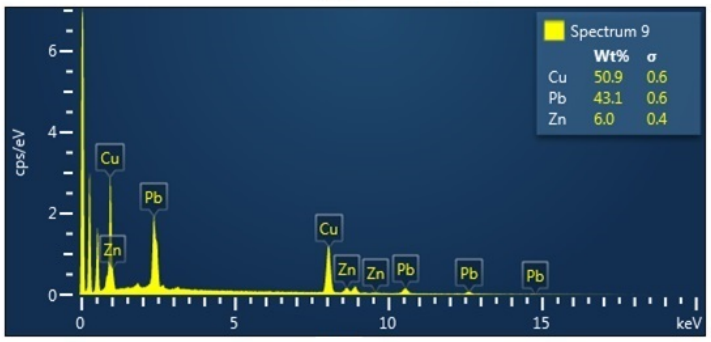

(d)

Figure 6. (a) Image showing morphology of cementation precipitate particles; (b) XRD analysis of precipitate; (c) SEM image of precipitate particle morphology; (d) EDX analysis after cementation using powder zinc.

Figure $6 c, d$ presents the results of SEM and EDX examinations of particles in the analysed sample of cementation precipitate. It follows from our EDX analysis that $\mathrm{Cu}, \mathrm{Pb}$ and $\mathrm{Zn}$ were present in the precipitate, predominantly $\mathrm{Cu}(\approx 33.8 \mathrm{wt} . \%)$ and $\mathrm{Pb}(\approx 16.89 \mathrm{wt} \%$ ). The precipitate also contained unreacted zinc $(\approx 5.25 \mathrm{wt} . \%)$. Table $3(\mathrm{~b})$ summarizes the results of the chemical analysis of the solution after the cementation process using powder zinc. This analysis demonstrates that the cementation succeeded in removing $\mathrm{Cu}$ as well as $\mathrm{Pb}$ from the solution. The increased amount of $\mathrm{Zn}$ in the solution after cementation was caused by the presence of more than the stoichiometric amount of zinc used as the cementer.

Table 3. Chemical analysis of solution (a) before and (b) after cementation.

\begin{tabular}{cccccc}
\hline & Concentration $[g / L]$ & $\mathbf{P b}$ & $\mathbf{Z n}$ & $\mathbf{F e}$ & $\mathbf{C u}$ \\
\hline (a) & Before cementation & 1.5706 & 8.756 & 0.0104 & 1.7138 \\
(b) & After cementation & 0.0012 & 10.28 & $<\mathrm{LoD}^{1}$ & 0.005 \\
\hline
\end{tabular}

${ }^{1}$ Note: $<$ LoD $^{2}$ below limit of detection.

\subsection{Influence of Zinc Surface Dimensions}

The influence of powder zinc particle size was investigated under ambient temperature conditions $(293 \mathrm{~K})$ and stirring rate $300 \mathrm{rpm}$. For cementation we used weighed amounts of $0.3 \mathrm{~g}$ powder zinc with two particle size distribution, namely $<0.125-0.4>\mathrm{mm}$ and $<0.08-0.125>\mathrm{mm}$. In both cases the initial and final $\mathrm{pH}$ values were the same at 4.2 
and 4.4, respectively. We also tried using a zinc-coated plate $(20 \mathrm{~mm} \times 35 \mathrm{~mm} \times 1 \mathrm{~mm})$ as cementer under the same experimental conditions as for powder zinc, apart from the stirring rate, which was set at $50 \mathrm{rpm}$. If more intensive stirring had been applied, excessive swirling would have occurred in the solution, which would not have been conducive to cementation or to the successful technical course of the experiment. The zinc plate was degreased with ethanol and rinsed with distilled water prior to the experiment. A $20 \mathrm{~mm}$ length of the plate was submerged in the solution. This form of cementation using a zinc plate proceeded rapidly, and within the first minute a layer of black cementation precipitate started covering the plate. The thickness of the precipitate layer increased with time, and later it began peeling off the plate. After $20 \mathrm{~min}$ we observed red particles appearing in the precipitate, which we assumed to be cemented out copper. The graph in Figure $7 \mathrm{a}$ shows the influence of powder Zn particle size on the concentration of lead in the solution during cementation at constant temperature $293 \mathrm{~K}$. The most suitable of the particle sizes investigated appeared to be that with distribution $<0.125-0.4>\mathrm{mm}$. After $30 \mathrm{~min}$ of cementation using powder zinc with this particle size, the $\mathrm{Pb}$ concentration in the solution reached its lowest value compared with the other particle size investigated. The steeper gradient of the curve for cementation using powder zinc with particle size distribution $<0.125-0.4>\mathrm{mm}$ compared with the curve produced by using the zinc plate indicates a higher rate of $\mathrm{Pb}$ cementation. Figure $7 \mathrm{~b}$ presents a graphical comparison of the efficiency of $\mathrm{Pb}$ cementation after five minutes of cementation using powder zinc with different particle sizes at constant temperature $293 \mathrm{~K}$. The highest efficiency after five minutes of cementation was achieved using powder zinc with particle size $<0.08-0.125>\mathrm{mm}$. At this time point we also measured the lowest $\mathrm{Pb}$ concentration in the solution using powder zinc with particle size $<0.08-0.125>\mathrm{mm}$, whereas after $15 \mathrm{~min}$ the $\mathrm{Pb}$ concentration in the solution was increased. This was probably caused by the zinc particles tending to cluster together (at around $10 \mathrm{~min}$ ), so that later (at around $15 \mathrm{~min}$ ) some retro-leaching of the lead started.

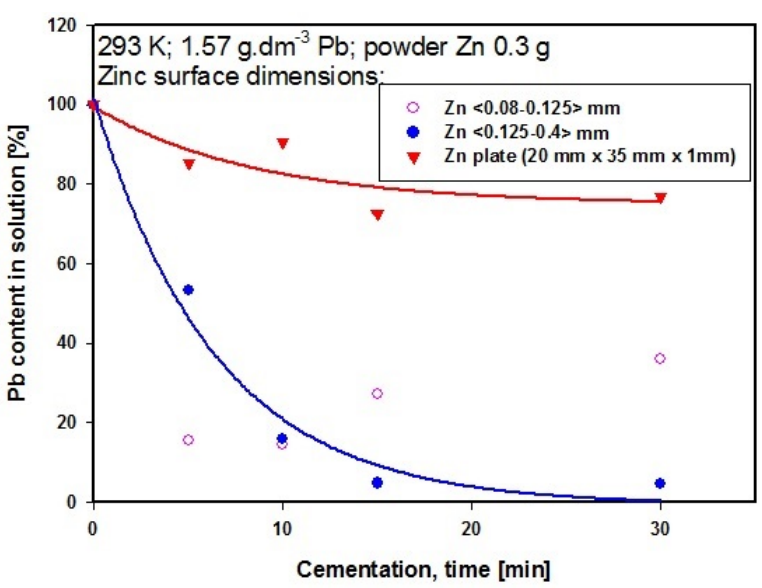

(a)

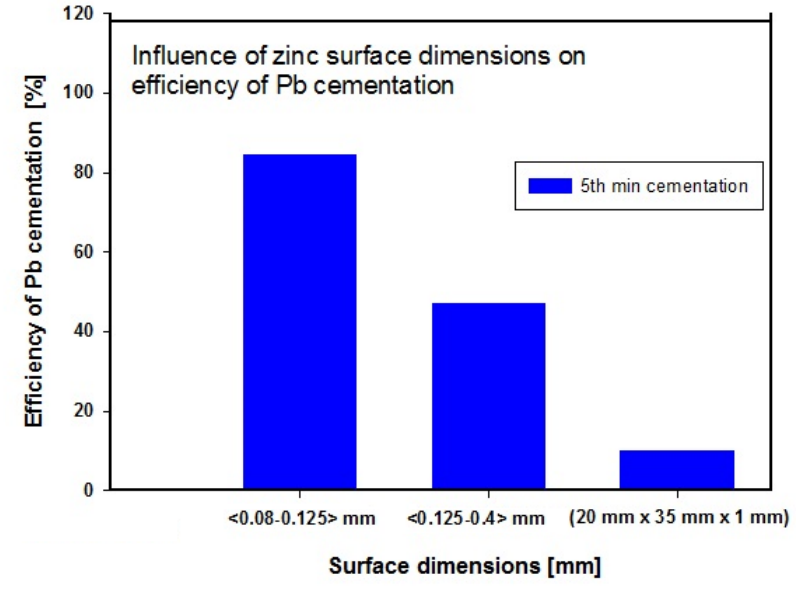

(b)

Figure 7. (a) Influence of cementer $\mathrm{Zn}$ particle size on $\mathrm{Pb}$ concentration in solution during cementation at $293 \mathrm{~K}$ (b) Comparison of $\mathrm{Pb}$ cementation efficiencies after 5 min procedure at $293 \mathrm{~K}$ using different $\mathrm{Zn}$ particle sizes.

\subsection{Investigation of Kinetics of Lead Cementation Process in Acid Medium}

The average chemical reaction rate (13) and in ion form (15) is expressed through Relation (17),

$$
\begin{aligned}
\mathrm{Zn}_{(\mathrm{s})}+\mathrm{Pb}\left(\mathrm{CH}_{3} \mathrm{CO}_{2}\right)_{2(\mathrm{aq})}= & \mathrm{Zn}\left(\mathrm{CH}_{3} \mathrm{COO}\right)_{2(\mathrm{aq})}+\mathrm{Pb}_{(\mathrm{s})} \quad \Delta \mathrm{G} 293_{\mathrm{K}}=-143.155 \mathrm{~kJ} \\
& \mathrm{Zn}^{0}+\mathrm{Pb}^{2+}=\mathrm{Zn}^{2+}+\mathrm{Pb}^{0}
\end{aligned}
$$




$$
\mathrm{v}=-\frac{\Delta \mathrm{c}_{\mathrm{Pb}} \mathrm{b}^{+}}{\Delta \mathrm{t}}\left[\mathrm{mol} \cdot \mathrm{dm}^{-3} \cdot \mathrm{s}^{-1}\right]
$$

whereby a negative value represents the change in concentration of lead-based ions over time. The calculated values of chemical reaction rate are given in Figure 8a.

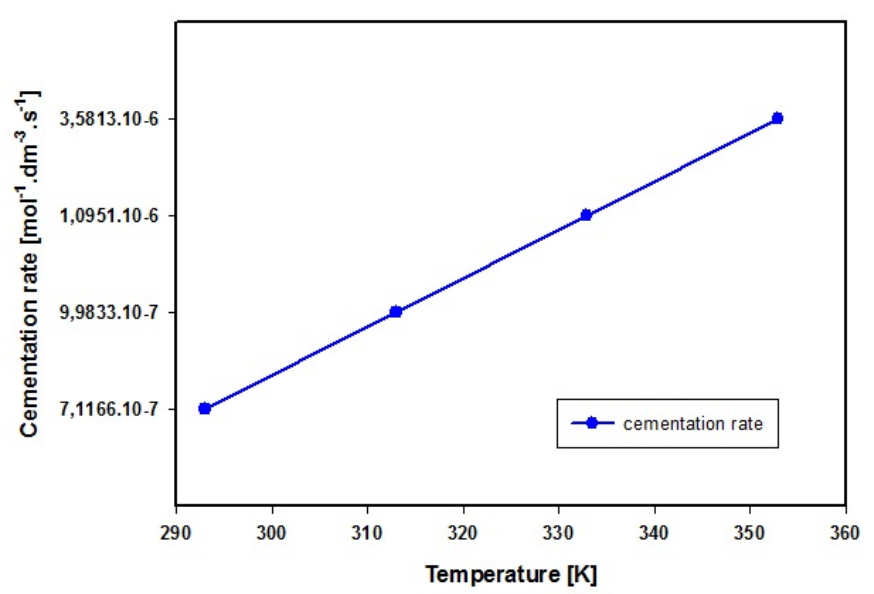

(a)

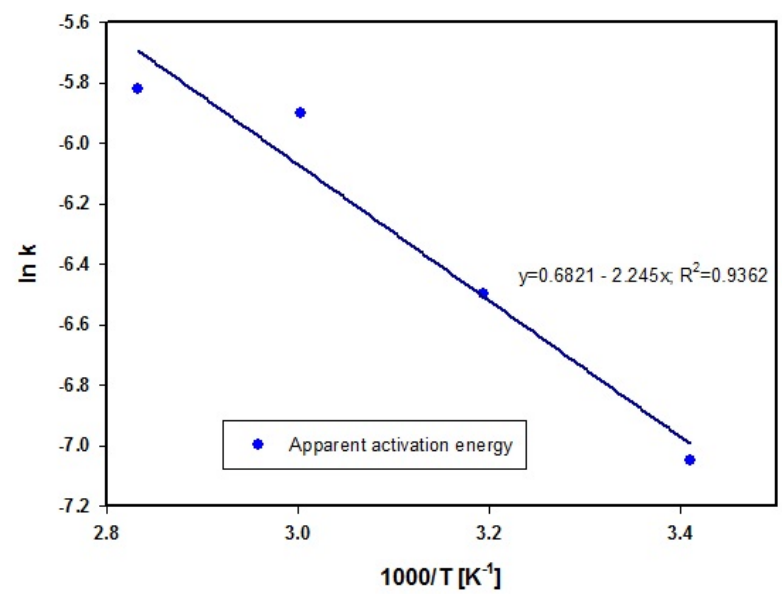

(b)

Figure 8. (a) Lead cementation rate at different temperatures of solution. (b) The Arrhenius equation expresses the interdependence of temperature and rate constant in chemical reactions.

Applying Arrhenius' equation in logarithmic form (17),

$$
\operatorname{lnk}=\ln \mathrm{A}-\frac{\mathrm{E}_{\mathrm{a}}}{\mathrm{RT}}
$$

where $\mathrm{k}=$ rate constant, $\mathrm{A}=$ frequency factor, $\mathrm{T}=$ temperature in Kelvin $(\mathrm{K})$ and $\mathrm{R}=$ universal gas constant, we calculated the value of apparent activation energy as $E_{a}=18.66 \mathrm{~kJ} \cdot \mathrm{mol}^{-1}$, which according to Zelikman et al., 1983 [45] indicates that the process of lead cementation in acetic acid solution proceeds in the diffusion zone in the temperature interval from 293 to $333 \mathrm{~K}$. The course of linear dependence lnk on 1000/T presented in Figure $8 \mathrm{~b}$ suggests similarly that the mechanism of lead cementation does not change within the temperature interval used here. The apparent activation energy $E_{a}$ determined using the linear regression method and Equation (20) is given in Figure 8b.

\section{Conclusions}

Secondary copper production using the pyrometallurgical route generates dust. Due to its heavy metals content and the fineness of its particles, this dust may represent a threat to the environment and to human health, so it is categorized as hazardous waste. According to the results of leachability testing in line with European standard EN 12457-1: 2002 [46], such dust may be stored only in hazardous waste dumps. On the other hand, because of its not inconsiderable non-ferrous metals content, such dust can be seen as a valuable secondary raw material. Research into dust processing currently focuses on use of the hydrometallurgical route for metals recovery.

This study focused on the experimental investigation of lead removal from acid solution after leaching of converter dust. The first step involved leaching of the dust in an acetic acid medium under ambient temperature conditions. Subsequently the process of lead cementation using zinc was studied, the aim of cementation being to remove the lead from the solution. The variables investigated for their influence on the efficiency of the cementation process were temperature of the medium, intensity of stirring and particle size of the powder zinc cementer. The kinetics of the process of lead cementation using 
powder zinc in acid medium was also studied. The main results of this experimental study are as follows:

(1) The highest efficiency of lead removal from the solution was achieved at ambient temperature $(293 \mathrm{~K})$ with stirring rate $300 \mathrm{rpm}$ and zinc particle size $<0.08-0.125>\mathrm{mm}$ after five minutes. Under these conditions almost $90 \%$ efficiency of lead removal from the solution was achieved. The cementation precipitate was found to contain copper as well as lead, which means that copper was also removed from the solution. Lead was represented in the precipitate in the phases $\mathrm{PbO}, \mathrm{Pb}_{5} \mathrm{O}_{8}$ and $\mathrm{Pb}\left(\mathrm{Cu}_{2} \mathrm{O}_{2}\right)$. Figure 9 presents suggested flowsheet for lead convert dust recycle process.

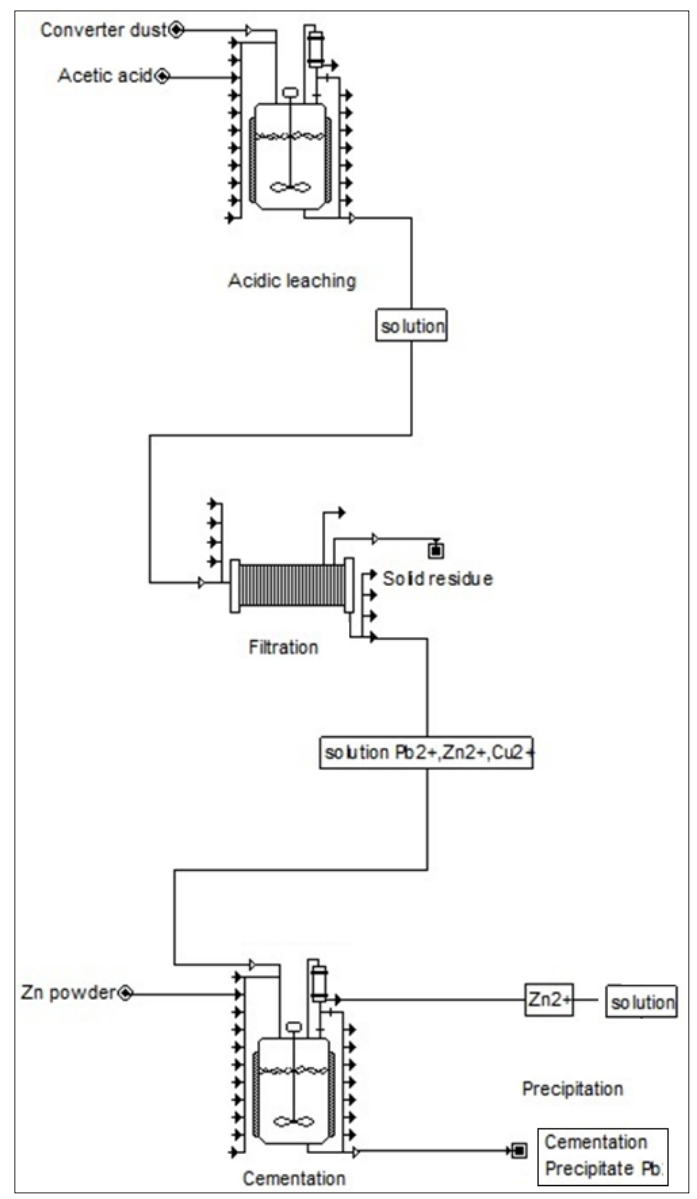

Figure 9. Suggested flowsheet for copper convert dust recycle process.

(2) Experimental measurements revealed the value of apparent activation energy as $\mathrm{E}_{\mathrm{a}}=18.66 \mathrm{~kJ} \cdot \mathrm{mol}^{-1}$, indicating that the process of lead cementation in acetic acid solution proceeds in the diffusion zone in the temperature interval from 293 to $333 \mathrm{~K}$. The course of linear dependence lnk on 1000/T suggests similarly that the mechanism of lead cementation does not change within the temperature interval used here. We established that stirring rate has greater impact on the chemical reaction rate than solution temperature.

Author Contributions: Conceptualization, M.L. and A.K.; methodology, M.L.; software, M.L.; validation, J.T., B.P. and J.B.; formal analysis, J.B. and B.P.; investigation, M.L. and A.K.; resources, A.K.; data curation, M.L.; writing—original draft preparation, M.L. and A.K.; writing—review and editing, M.L.; visualization, M.L.; supervision, J.T.; project administration, J.T.; funding acquisition, J.T. All authors have read and agreed to the published version of the manuscript.

Funding: This research was funded by the Ministry for Education of the Slovak Republic, grant number VEGA 1/0641/20. 
Data Availability Statement: The data presented in this study are available on request from the corresponding author.

Acknowledgments: This work was supported by the Ministry for Education of the Slovak Republic under grant MŠ SR VEGA 1/0641/20.

Conflicts of Interest: The authors declare no conflict of interest.

\section{References}

1. U.S. Geological Survey. Mineral Commodity Summaries 2021: Sand and Gravel (Industrial); U.S. Geological Survey: Reston, VA, USA, 2021; ISBN 9781411343986.

2. Demand, V. Copper Drives Electric Vehicles. Available online: https://www.copper.org/publications/pub_list/pdf/A6191ElectricVehicles-Factsheet.pdf (accessed on 29 October 2021).

3. Lynch, J. Copper's Role in Growing Electric Vehicle Production. Available online: https://www.reuters.com/article/sponsored/ copper-electric-vehicle (accessed on 20 October 2021).

4. McGuiness, P.J.; Ogrin, R. Securing Technology-Critical Metals for Britain: Ensuring the United Kingdom's Supply of Strategic Elements $\mathcal{E}$ Critical Materials for a Clean Future; University of Birmingham: Birmingham, UK, 2021; ISBN 9780704429697.

5. Top Ten Global Copper Producers-2020. Available online: https://nma.org/wp-content/uploads/2021/07/Top-Ten-CopperProducers-2020.pdf (accessed on 22 October 2021).

6. Kovohuty Krompachy. Available online: https://www.kovohuty.sk/home.html (accessed on 29 October 2021).

7. Havlík, T. Hydrometallurgy Principles and Applications; Woodhead Publishing Limited: Southston, UK, 2008; ISBN 978-1-84569-407-4.

8. Orac, D.; Laubertova, M.; Piroskova, J.; Klein, D.; Bures, R.; Klimko, J. Characterization of dusts from secondary copper production. J. Min. Metall. Sect. B Metall. 2020, 56, 221-228. [CrossRef]

9. Forsén, O.; Aromaa, J.; Lundström, M. Primary copper smelter and refinery as a recycling plant-a system integrated approach to estimate secondary raw material tolerance. Recycling 2017, 2, 19. [CrossRef]

10. Waste Production and Waste Management in the Slovak Republic. Available online: http://cms.enviroportal.sk/odpady/verejneinformacie.php?rok=B-2017\&kr=v\&kat\%5B\%5D=100603\&kat \%5B \%5D=100606 (accessed on 20 October 2021).

11. European Waste Catalogue and Hazardous Waste List. Available online: http:/ /www.nwcpo.ie/forms/EWC_code_book.pdf (accessed on 20 October 2021).

12. Balladares, E.; Kelm, U.; Helle, S.; Parra, R.; Araneda, E. Chemical-mineralogical characterization of copper smelting flue dust. Dyna 2014, 81, 11. [CrossRef]

13. Guo, L.; Lan, J.; Du, Y.; Zhang, T.C.; Du, D. Microwave-enhanced selective leaching of arsenic from copper smelting flue dusts. J. Hazard. Mater. 2020, 386, 121964. [CrossRef]

14. Kukurugya, F.; Vindt, T.; Havlík, T. Behavior of zinc, iron and calcium from electric arc furnace (EAF) dust in hydrometallurgical processing in sulfuric acid solutions: Thermodynamic and kinetic aspects. Hydrometallurgy 2015, 154, 20-32. [CrossRef]

15. Trung, Z.H.; Kukurugya, F.; Takacova, Z.; Orac, D.; Laubertova, M.; Miskufova, A.; Havlik, T. Acidic leaching both of zinc and iron from basic oxygen furnace sludge. J. Hazard. Mater. 2011, 192, 1100-1107. [CrossRef] [PubMed]

16. Laubertová, M.; Pirošková, J.; Dociová, S. The technology of lead production from waste. World Metall. - ERZMETALL 2017, 70, 47-54.

17. Okanigbe, D.O.; Popoola, A.P.I.; Adeleke, A.A.; Otunniyi, I.O.; Popoola, O.M. Investigating the impact of pretreating a waste copper smelter dust for likely higher recovery of copper. Procedia Manuf. 2019, 35, 430-435. [CrossRef]

18. Maruskinova, G.; Kukurugya, F.; Parilak, L.; Havlik, T.; Kobialkova, I. Hydrometallurgical treatment of EAF steelmaking dust. Metall 2015, 68, 522-524.

19. Pirošková, J.; Laubertová, M.; Miškufová, A.; Oráč, D. Hydrometallurgical treatment of copper shaft furnace dust for lead recovery. World Metall. - ERZMETALL 2018, 71, 37-42.

20. Ghica, V.G.; Buzatu, T. Cemention with iron in solutions of lead acetate in a two-step process. Rev. Chim. 2013, 64, 580-583.

21. Volpe, M.; Oliveri, D.; Ferrara, G.; Salvaggio, M.; Piazza, S.; Italiano, S.; Sunseri, C. Metallic lead recovery from lead-acid battery paste by urea acetate dissolution and cementation on iron. Hydrometallurgy 2009, 96, 123-131. [CrossRef]

22. Farahmand, F.; Moradkhani, D.; Sadegh Safarzadeh, M.; Rashchi, F. Optimization and kinetics of the cementation of lead with aluminum powder. Hydrometallurgy 2009, 98, 81-85. [CrossRef]

23. Siegmund, A.; Shibata, E.; Alam, S.; Grogan, J.; Kerney, U. PbZn 2020: 9th International Symposium on Lead and Zinc Processing; Springer Nature: Cham, Switzerland, 2020; Volume 53, ISBN 9788578110796.

24. Silwamba, M.; Ito, M.; Hiroyoshi, N.; Tabelin, C.B. Recovery of Lead and Zinc from Zinc Plant Leach Residues by Concurrent Dissolution-Cementation. Metals 2020, 10, 531. [CrossRef]

25. Abdollahi, P.; Yoozbashizadeh, H.; Moradkhani, D.; Behnian, D. A Study on Cementation Process of Lead from Brine Leaching Solution by Aluminum Powder. OALib 2015, 2, 1-6. [CrossRef]

26. Forte, F.; Horckmans, L.; Broos, K.; Kim, E.; Kukurugya, F.; Binnemans, K. Closed-loop solvometallurgical process for recovery of lead from iron-rich secondary lead smelter residues. RSC Adv. 2017, 7, 49999-50005. [CrossRef]

27. Gargul, K.; Boryczko, B.; Bukowska, A.; Jarosz, P.; Małecki, S. Leaching of lead and copper from flash smelting slag by citric acid. Arch. Civ. Mech. Eng. 2019, 19, 648-656. [CrossRef] 
28. Liu, W.F.; Fu, X.X.; Yang, T.Z.; Zhang, D.C.; Chen, L. Oxidation leaching of copper smelting dust by controlling potential. Trans. Nonferrous Met. Soc. China Engl. Ed. 2018, 28, 1854-1861. [CrossRef]

29. Raghavan, R.; Mohanan, P.K.; Patnaik, S.C. Innovative processing technique to produce zinc concentrate from zinc leach residue with simultaneous recovery of lead and silver. Hydrometallurgy 1998, 48, 225-237. [CrossRef]

30. Gabler, R.C.; Jones, J.R. Metal Recovery from Secondary Copper Converter Dust by Ammoniacal Carbonate Leaching; Bureau of Mines: Washington, DC, USA, 1988; p. 8.

31. Oráč, D.; Hlucháňová, B.; Havlík, T.; Miškufová, A.; Petrániková, M. Leaching of zinc and copper from blast furnace dust of copper production of secondary raw materials. Acta Metall. Slovaca 2009, 3, 147-153.

32. Soria-Aguilar, M.J.; Carrillo-Pedroza, F.R.; Preciado-Nuñez, S. Treatment of BF and BOF dusts by oxidative leaching. In Proceedings of the 2008 Global Symposium on Recycling, Waste Treatment and Clean Technology, REWAS, Cancun, Mexico, 12-15 October 2008.

33. Sabzezari, B.; Koleini, S.M.J.; Ghassa, S.; Shahbazi, B.; Chelgani, S.C. Microwave-leaching of copper smelting dust for Cu and Zn extraction. Materials 2019, 12, 1822. [CrossRef]

34. Laubertova, M.; Havlik, T.; Parilak, L.; Derin, B.; Trpcevska, J. The effects of microwave-assisted leaching on the treatment of electric arc furnace dusts (EAFD). Arch. Metall. Mater. 2020, 65, 321-328. [CrossRef]

35. Tzaneva, B. Electrochemical investigation of cementation process. Bulg. Chem. Commun. 2016, 48, 91-95.

36. Shishkin, A.; Mironovs, V.; Vu, H.; Novak, P.; Baronins, J.; Polyakov, A.; Ozolins, J. Cavitation-dispersion method for copper cementation from wastewater by iron powder. Metals 2018, 8, 920. [CrossRef]

37. Panão, A.S.I.; De Carvalho, J.M.R.; Correia, M.J.N. Copper Removal from Sulphuric Leaching Solutions by Cementation. 2006. Available online: https:/ / www.semanticscholar.org/paper/Copper-Removal-from-Sulphuric-Leaching-Solutions-by-PanaoCarvalho/3a21ea867265ed4638524d9f13e08ced3d6359e1 (accessed on 20 October 2021).

38. Makhloufi, L.; Saidani, B.; Hammache, H. Removal of lead ions from acidic aqueous solutions by cementation on iron. Water Res. 2000, 34, 2517-2524. [CrossRef]

39. Kazakova, N.; Lucheva, B.; Iliev, P. A study on the cementation process of non-ferrous metals from a brine leaching solution. J. Chem. Technol. Metall. 2020, 55, 223-227.

40. Klimko, J.; Kobialkova, I.U.; Piroskova, J.; Orac, D.; Havlik, T.; Klein, D. Sustainable development in the tinplate industry: Refining tinplate leachate with cementation. Physicochem. Probl. Miner. Process. 2020, 56, 219-227. [CrossRef]

41. Demirkran, N.; Künkül, A. Recovering of copper with metallic aluminum. Trans. Nonferrous Met. Soc. China Engl. Ed. 2011, 21, 2778-2782. [CrossRef]

42. Stankovic, V. Cementation of Copper Onto Brass Particles in a Packed Bed. J. Min. Metall. 2004, 40, 21-39. [CrossRef]

43. De Oliveira, V.A.A.; Penna, J.M.S.; Magalhães, L.S.; Leão, V.A.; dos Santos, C.G. Kinetics of Copper and Cadmium Cementation By Zinc Powder. Tecnol. em Metal. Mater. e Min. 2019, 16, 255-262. [CrossRef]

44. Demirkiran, N.; Ekmekyapar, A.; Künkül, A.; Baysar, A. A kinetic study of copper cementation with zinc in aqueous solutions. Int. J. Miner. Process. 2007, 82, 80-85. [CrossRef]

45. Zelikman, A.H.; Vol'dman, G.M.; Beljajevskaja, L.V. Teoria Gidrometallurgičeskich Processov; Moskva Metallurgija: Moskva, Russia, 1975; p. 503.

46. European Standard EN 12457-1:2002. Characterisation of Waste. Leaching. Compliance Test for Leaching of Granular Waste Materials and Sludges; European Union: Maastricht, The Netherlands, 2006. 